\title{
Molecular-Genetic Polymorphisms of Dopamine, Serotonin and Androgenic Systems as Molecular Markers of Success in Judo Wrestling Sportsmen
}

Polina R Butovskaya ${ }^{1,2}$, Marina L Butovskaya ${ }^{3}$, Vasiliy A Vasilyev², Oleg E Lazebny ${ }^{4 *}$, Dmitri V Shibalev², Elizaveta V Veselovskaya ${ }^{3}$, Irina G Udina ${ }^{1}$ and Alexey P Ryskov ${ }^{2}$

${ }^{1}$ Vavilov Institute of General Genetics, Russian Academy of Sciences, Moscow 119991, Russian Federation ${ }^{2}$ Institute of Gene Biology, Russian Academy of Sciences, Moscow 119334, Russian Federation

${ }^{3}$ Institute of Ethnology and Anthropology, Russian Academy of Sciences, Moscow, 119991, Russian Federation

${ }^{4}$ Kol'tsov Institute of Developmental Biology, Russian Academy of Sciences, Moscow, 119334, Russian Federation

\begin{abstract}
In this study we tested gene-candidates, associated with the stress-resistance and personality traits, aggression in particular, in 16 world-class judo sportsmen, and 40 young men as a control sample from general Russian population (all men were of Caucasian origin). The polygenic profile with 9 candidate genes which included 10 polymorphisms (i.e., AR, DRD4, DRD2, DAT1, COMT, 5-HTTL, MAOA, HTR1A and HTR2A) connected to the functioning of serotonin, dopamine, and androgenic systems were determined. It was demonstrated that judo sportsmen significantly differed from the control group by higher frequencies of AR alleles with lower numbers of CAG repeats, V/V genotype of COMT gene, and G/G genotype of HTR1A gene, thus suggesting these polymorphisms as genetic markers of sportive success in wrestling.
\end{abstract}

Keywords: Wrestling performance; Candidate genes of dopamine; Serotonin and androgenic systems; Genetic polymorphism; Biomarkers

\section{Introduction}

The making of an elite sportsman is composite and includes a complex interaction of genetic predisposition to athleticism with environmental and behavior factors. The heritability for individual traits is a highly important source of information for people responsible for planning training. With the rapid development of molecular research in sport a few dozens of genetic markers connected with physical performance, cardiorespiratory and functional muscle properties in the first rate were detected (ACE, ACTN3, AMPD1, CKMM, HFE, GDF-8, NOS3, PPARGC1A, UCP2, and UCP3) [1-5]. Although, the modern sport is associated with a huge emotional and psychological pressure on athletes and endurance of stress nowadays has becoming a key important factor of sportive achievements. The ability to control personal negative emotions and aggression, as well as to tolerate various types of provocation from opponents is particular important in wrestling (judo and Greek-roman wrestling in particular). For this extent it is highly important to study the gene-candidates, associated with behavioral traits in sportsmen [6-8]. Phenotypic expression of personality traits is an outcome of activity of many polymorphic genes, associated with dopamine, serotonin and androgenic systems and providing a different level of genes expression, and (or) functional activity of gene products.

The androgen receptor gene (AR) in exon 1 contains from 8 to 35 triplet repeats CAG (a microsatellite cluster), coding for a glutamine array. It was demonstrated that the lower number of CAG repeats the receptor is more sensitive to androgens. The CAG repeat polymorphisms of the AR gene play an important role in aggressive behavior [9].

In promoter region, the serotonin transporter gene (5-HTTL) was found to contain CG- rich tandem repeats (VNTR). There are two major allelic variants of the gene which differ in transcriptional activity, short allele (S) and long allele (L) [10]. In case of two or one copies of S allele the transcription is lower in comparison with $\mathrm{L}$ allele homozygous. Later, the SNP in repeat 6 of $\mathrm{L}$ and $\mathrm{S}$ alleles $(\mathrm{A} / \mathrm{G})$ of 5-HTTL gene was found. This mutant allele $G$ is proved to affect the transcription of L allele [11].

For promoter region of serotonin receptor gene (HTR1A) the SNP G1019C was extensively studied. This polymorphism was showed to influence on the level of gene expression because it was demonstrated that the transcription level of $\mathrm{G}$ allele is much higher that of $\mathrm{C}$ allele. The serotonin receptor gene (HTR2A) contains SNP A/G1438, which seems to be a genetic marker for human aggressive behavior [12] Homozygote genotype HTR2A GG appears to be the marker of a lower risk, while the presence at least of one copy of A allele in genotype is a marker of a higher risk. In promoter region of monoamine oxidase gene (MAOA) the VNTR was found, the number of repeats varies from two to five. The transcription of the gene with two and three repeats is five times lower and as a consequence the level of serotonin in organism is higher [13]. Both SNPs and insertion/deletion polymorphism were found in the promoter region of DRD4 gene [14]. This marker is worth noting in view with its possible association with different forms of aggressive behavior [15]. Exon 3 of DRD4 gene (DRD4E3) contains variable number of repeats, from 2 to 11. DRD4 allele 7 was associated with a lower DRD4 sensitivity to stimuli [16].

*Corresponding author: Oleg E Lazebny, Kol'tsov Institute of Developmental Biology, Russian Academy of Sciences, Russian Federation, Tel: 749-913-587-81: Fax: 7-499-135-8012; E-mail: oelazebny@gmail.com

Received February 27, 2013; Accepted March 23, 2013; Published March 26 2013

Citation: Butovskaya PR, Butovskaya ML, Vasilyev VA, Lazebny OE, Shibalev DV, et al. (2013) Molecular-Genetic Polymorphisms of Dopamine, Serotonin and Androgenic Systems as Molecular Markers of Success in Judo Wrestling Sportsmen. J Bioanal Biomed S3: 005. doi:10.4172/1948-593X.S3-005

Copyright: (C 2013 Butovskaya PR, et al. This is an open-access article distributed under the terms of the Creative Commons Attribution License, which permits unrestricted use, distribution, and reproduction in any medium, provided the original author and source are credited. 
Citation: Butovskaya PR, Butovskaya ML, Vasilyev VA, Lazebny OE, Shibalev DV, et al. (2013) Molecular-Genetic Polymorphisms of Dopamine, Serotonin and Androgenic Systems as Molecular Markers of Success in Judo Wrestling Sportsmen. J Bioanal Biomed S3: 005. doi:10.4172/1948-593X.S3-005

The (DRD2) gene contains SNP located in 3'-noncoding region (Taq1 A polymorphism). Defined polymorphism may serve as a biological marker of the expression level and function of dopamine receptor D2. It was demonstrated that the genotypes $\mathrm{A} 1 / \mathrm{A} 1$ и $\mathrm{A} 1 / \mathrm{A} 2$ of DRD2 gene are twice as frequent in people with higher level of aggression [17]. The dopamine transporter gene (DAT1) contains VNTR in 3-noncoding region with variable repeats number from 3 to 12 . Allele with 10 repeats was associated with higher expression level of transporter protein and therefore with a lower accessibility of dopamine for its receptors [16]. Codon 158 of gene catechol O-methiltransferase (COMT) has a transition-type SNP 108A/G or Val158Met. Val158Met is a functional polymorphism because the substitution of $\mathrm{G}$ for $108 \mathrm{~A}$ decreases the enzymatic activity by a factor of $\mathbf{3 - 4}$ and is known as allele COMTL [18].

Here, we analyzed all mentioned above polymorphisms of 9 genes (AR, DRD4, DRD2, DAT1, COMT, 5-HTTL, MAOA, HTR1A и HTR2A) in judo wrestlers, and in control group of the same age.

\section{Materials and Methods}

Buccal epithelium samples for DNA analysis were collected in Moscow 2006-2008. Participants were young men with the age range from 18 to 30 years, including the world-class judo athletes $(n=16)$ and control sample for general Russian population $(n=40)$. Young man from control group was doing neither any fitness or amateur sport. All participants were of Caucasian origin. All aspects of the study were approved by the ethical committee of Moscow State University. The consent was obtained from all subjects before they participated in the study.

DNA extraction and DRD4Pr, DRD4E3, AR и 5HTTLPr loci polymorphism study was performed as mentioned before $[9,13]$. In table 1 there are the primers sequences and the annealing temperatures. The polymerase chain reaction was performed with the GenePack PCR MasterMix Core (IsoGene Lab Russia) reagent kit. The amplification profile was the following: initial denaturation at $94^{\circ} \mathrm{C}-4$ minutes; 30 cycles consisting of three steps, including denaturation for 1 minute, primer annealing for 1 minute at $\mathrm{X}^{\circ} \mathrm{C}$ (Table 1) and elongation for 1 minute at $72^{\circ} \mathrm{C}$ and final elongation at $72^{\circ} \mathrm{C}$ for 10 minutes. To identify the Taq1A-polymorphism in gene DRD2 the amplification product was divided into $10 \mathrm{Ml}$ aliquots, with one of this treated with the TaqI restriction endonucleases at $65^{\circ} \mathrm{C}$ overnight. To identify Val158Metpolymorphism in COMT gene the amplification product was divided into $10 \mathrm{ml}$ aliquots, with one of this treated with Nla III restriction

\begin{tabular}{|c|l|c|}
\hline Loci & \multicolumn{1}{|c|}{ Primer sequences } & $\begin{array}{c}\text { Annealing } \\
\text { temperature }\end{array}$ \\
\hline MAOA VNTR & $\begin{array}{l}\text { F5'-ACAGCTGACCGTGGAGAAG-3' } \\
\text { R 5'- TCCGAATGGAGCGTCGTTC-3' }\end{array}$ & $66^{\circ} \mathrm{C}$ \\
\hline $\begin{array}{c}\text { G1019C } \\
\text { HTR1A, }\end{array}$ & $\begin{array}{l}\text { F 5'-GGCTGGACTGTTAGATGATAACG-3' } \\
\text { R 5'-GGAAGAAGACCGAGTGTGTCAT-3' } \\
\text { HTR2A }\end{array}$ & $\begin{array}{l}\text { F 5'-AACCAACTTATTTCCTACCAC -3' } \\
\text { R 5'- AAGCTGCAAGGTAGCAACAGC -3' }\end{array}$ \\
\hline DRD2-Taq1 A & $\begin{array}{l}\text { F: 5'- CCGTCGACGGCTGGCCAAGTTGTCTA-3' } \\
\text { R: 5'-CCGTCGACCCTTCCTGAGTGTCATCA-3' }\end{array}$ & $60^{\circ} \mathrm{C}$ \\
\hline DAT1 VNTR & $\begin{array}{l}\text { F: 5'-TGCGGTGTAGGGAACGGCCTGAG-3' } \\
\text { R: 5'-CTTCCTGGAGGTCACGGCTCAAGG-3' }\end{array}$ & $68^{\circ} \mathrm{C}$ \\
\hline COMT M'158V & $\begin{array}{l}\text { F: 5'-TACTGTGGCTACTCAGCTGTGC-3' } \\
\text { R: 5'-GTGAACTGTGTGTGAACACC-3' }\end{array}$ & $5^{\circ} 5^{\circ} \mathrm{C}$ \\
\hline
\end{tabular}

${ }^{*} \mathrm{~F}$ - forward, $\mathrm{R}$ - reverse

Table 1: Primer sequences and annealing temperatures used loci. endonucleases at $37^{\circ} \mathrm{C}$ overnight. To identify G1019C polymorphism in HTR1A gene the amplification product was divided into $10 \mathrm{ml}$ aliquots, with one of this treated with BseGI restriction endonucleases at $55^{\circ} \mathrm{C}$ overnight. To identify A1438G-polymorphism in HTR2A gene the amplification product was divided into $10 \mathrm{Ml}$ aliquots, with one of this treated with MspI restriction endonucleases at $37^{\circ} \mathrm{C}$ overnight.

Amplification and restriction products were separated by electrophoresis in 2\% agarose gel for loci (DRD2, DAT1, MAOA, DRD2, 5-HTTLPR, HTR1A, HTR2A) and in 3\% agarose gel (NuSieve) for COMT locus and stained with ethidium bromide. The results were photographed and analyzed using BioDocAnalyze device (Biometra, Goettingen, Germany). The amplification products of loci AR and DRD4E3 were analyzed according to protocol published before [9].

Statistical treatment of the data was performed using following programs PopGenev.1.31, Genepop v.4.2, SPSS-15. All probabilities obtained in multiple tests were Bonferroni adjusted.

\section{Results and Discussion}

In this study 10 polymorphisms (9 genes), connected with dopaminergic, serotonergic and androgenic systems, suggestively associated with personality traits, such as aggressiveness, risk taking, neuroticism, stress-resistance, in world-class men judo athletes and control sample were analyzed. Judo athletes and control group did not differ significantly in distribution of allele frequencies for the most polymorphisms tested (Table 2) except of the SNP at the COMT gene ( $\mathrm{p}=0.034$, exact Fisher test).

According to the results obtained for both samples and for the majority of polymorphisms studied, there were no significant departures from the Hardy-Weinberg equilibrium except of the SNP at gene HTR1A ( $\mathrm{p}=0.003)$ in the wrestle sample. The certain deficiency of heterozygotes was significant $(\mathrm{D}=-0.750 \pm 0.0625, \mathrm{p}<0.001)$ in wrestlers. This may be due to specifics of sample collection and small sample size. The frequency of genotype G/G at this locus (Table 3) is significantly higher in athletes than in the control sample $(p=0.016$, Fisher exact test). This result is in a good accordance with the data on more intensive expression of allele G [12].

Analysis of the genotype distributions demonstrated significantly higher frequency of $\mathrm{V} / \mathrm{V}$ genotype of the COMT gene $(\mathrm{p}=0.028$, Fisher exact test) as well as of genotype G/G at HTR1A locus ( $p=0.016$, Fisher exact test) in athletes comparing to controls. The difference for the distribution of all three genotypes of the last loci was $\mathrm{G}=11.93$, d.f. $=2, p=0.0026$. Thus, wrestlers had a higher frequency of highlevel expression genotype V/V (V158M) for the gene for catechol-Omethyl-transferase, which can serve as a genetic marker of their ability to control their own physical aggression. Similar data were obtained by [19] for women athletes: their physical aggression was significantly reduced in a number of genotypes following $\mathrm{V} / \mathrm{V}<\mathrm{M} / \mathrm{V}<\mathrm{M} / \mathrm{M}$.

Comparing two samples with the use of Wright's fixation index $\left(\mathrm{F}_{\mathrm{ST}}\right)$ indicated the absence of significant differences between athletes and the control sample for the all polymorphisms studied except for COMT and AR. $\mathrm{F}_{\mathrm{ST}}$ values for the latter two loci were $\mathrm{F}_{\mathrm{ST}}=0.089$, $\mathrm{p}=0.039$ and $\mathrm{F}_{\mathrm{ST}}=0.051, \mathrm{p}=0.027$, respectively, indicating the difference in genetic structure between the control and athletes.

For the studied microsatellite polymorphism of AR gene the average number of CAG repeats was $24.24 \pm 0.40$. Based on the mean 
Citation: Butovskaya PR, Butovskaya ML, Vasilyev VA, Lazebny OE, Shibalev DV, et al. (2013) Molecular-Genetic Polymorphisms of Dopamine, Serotonin and Androgenic Systems as Molecular Markers of Success in Judo Wrestling Sportsmen. J Bioanal Biomed S3: 005. doi:10.4172/1948-593X.S3-005

Page 3 of 6

value, we divided both samples into two groups of genotypes, with a low number of repeats ( 24 or less) and a high number of repeats $(25$ or more).

Comparison of the frequency distribution of AR genotypes in athletes and controls using Fisher's exact test indicated significant

\begin{tabular}{|c|c|c|}
\hline Gene/ allele & Judo group & Control group \\
\hline & $\mathrm{ps}_{\mathrm{p}}$ & $\mathrm{ps}_{\mathrm{p}}$ \\
\hline COMT & $\mathrm{N}=16$ & $\mathrm{~N}=35$ \\
\hline V & $0.656 \pm 0.119$ & $0.414 \pm 0.083$ \\
\hline$M$ & $0.344 \pm 0.119$ & $0.586 \pm 0.083$ \\
\hline$D R D 4 P r$ & $N=16$ & $\mathrm{~N}=40$ \\
\hline$L$ & $0.781 \pm 0.103$ & $0.838 \pm 0.058$ \\
\hline$S$ & $0.219 \pm 0.103$ & $0.163 \pm 0.058$ \\
\hline 5HTTLPR & $N=16$ & $\mathrm{~N}=40$ \\
\hline$L_{A}$ & $0.500 \pm 0.125$ & $0.563 \pm 0.078$ \\
\hline$S_{A}$ & $0.469 \pm 0.125$ & $0.388 \pm 0.077$ \\
\hline$L_{G}$ & $0.031 \pm 0.043$ & $0.050 \pm 0.034$ \\
\hline HTR1A & $\mathrm{N}=16$ & $\mathrm{~N}=40$ \\
\hline C & $0.500 \pm 0.125$ & $0.575 \pm 0.078$ \\
\hline G & $0.500 \pm 0.125$ & $0.425 \pm 0.078$ \\
\hline HTR2A & $N=16$ & $N=36$ \\
\hline$A$ & $0.344 \pm 0.119$ & $0.375 \pm 0.081$ \\
\hline$G$ & $0.656 \pm 0.119$ & $0.625 \pm 0.081$ \\
\hline$D R D 4 E 3$ & $N=15$ & $N=39$ \\
\hline 2 & $0.067 \pm 0.064$ & $0.103 \pm 0.049$ \\
\hline 3 & $0.000 \pm 0.000$ & $0.026 \pm 0.025$ \\
\hline 4 & $0.733 \pm 0.114$ & $0.718 \pm 0.072$ \\
\hline 5 & $0.000 \pm 0.000$ & $0.013 \pm 0.018$ \\
\hline 7 & $0.200 \pm 0.103$ & $0.141 \pm 0.056$ \\
\hline$D R D 2$ & $\mathrm{~N}=16$ & $N=38$ \\
\hline$A 1$ & $0.063 \pm 0.061$ & $0.197 \pm 0.065$ \\
\hline$A 2$ & $0.938 \pm 0.061$ & $0.803 \pm 0.065$ \\
\hline DAT1 & $N=16$ & $\mathrm{~N}=40$ \\
\hline 8 & $0.000 \pm 0.000$ & $0.013 \pm 0.018$ \\
\hline 9 & $0.156 \pm 0.091$ & $0.250 \pm 0.068$ \\
\hline 10 & $0.844 \pm 0.091$ & $0.725 \pm 0.071$ \\
\hline 11 & $0.000 \pm 0.000$ & $0.013 \pm 0.018$ \\
\hline$M A O A$ & $N=16$ & $N=39$ \\
\hline 3 & $0.375 \pm 0.121$ & $0.513 \pm 0.080$ \\
\hline 4 & $0.625 \pm 0.121$ & $0.487 \pm 0.080$ \\
\hline$A R$ & $N=15$ & $\mathrm{~N}=40$ \\
\hline 17 & $0.000 \pm 0.000$ & $0.025 \pm 0.025$ \\
\hline 20 & $0.200 \pm 0.103$ & $0.050 \pm 0.034$ \\
\hline 21 & $0.000 \pm 0.000$ & $0.025 \pm 0.025$ \\
\hline 22 & $0.067 \pm 0.064$ & $0.200 \pm 0.063$ \\
\hline 23 & $0.267 \pm 0.114$ & $0.100 \pm 0.047$ \\
\hline 24 & $0.267 \pm 0.114$ & $0.075 \pm 0.042$ \\
\hline 25 & $0.067 \pm 0.064$ & $0.100 \pm 0.047$ \\
\hline 26 & $0.067 \pm 0.064$ & $0.300 \pm 0.072$ \\
\hline 27 & $0.000 \pm 0.000$ & $0.050 \pm 0.034$ \\
\hline 28 & $0.000 \pm 0.000$ & $0.025 \pm 0.025$ \\
\hline 29 & $0.000 \pm 0.000$ & $0.025 \pm 0.025$ \\
\hline 30 & $0.067 \pm 0.064$ & $0.000 \pm 0.000$ \\
\hline 31 & $0.000 \pm 0.000$ & $0.025 \pm 0.025$ \\
\hline
\end{tabular}

$\mathrm{p}$ - allele frequency, $\mathrm{s}_{\mathrm{p}}$ - standard error.

Table 2: Alleles frequencies for studied loci in Judo and Control groups. differences between the samples $(\mathrm{p}=0.029)$. It was shown that the frequency of genotypes of the androgen receptor gene with a lower number of repeats CAG (less than 24 repeats) in male wrestlers were significantly higher compared to control. According to the literature, sensitivity of androgen receptors with a low number of CAG repeats increases significantly [20].

The association between the lower number of CAG-repeats in AR gene and masculinity, particular with the lower digit ratio (2D:4D) in men from the population of the Hadza (traditional East African huntergatherers) had been recently found [9]. Also, the data from China have indicated that AR CAG repeat polymorphism was associated with the exercise performance after simulated normobaric hypoxic training in North China Han men, and that the shorter genotypes (21 repeats and lower) had a better individual response to hypoxic training, compared to the carries of longer variants (22 repeats and longer) [21]. It was demonstrated, that both men and women elite athletes (wrestlers and football players), had significantly lower $2 \mathrm{D}: 4 \mathrm{D}$ ratios compared to control samples $[22,23]$. Currently it was mentioned that variation in AR has been linked to handedness [24,25]. Later this association had been linked with success in fighting [26]. Although in this study we are not discussing these correlations, taken together all the data mentioned above, we may conclude that CAG repeats AR gene polymorphism may be suggested as a potential gene marker of sportive success. This conclusion confirms the original hypothesis of Manning and Taylor on existence of correlations between the morphologic and the physiologic masculinity and the lower number of CAG repeats in AR gene [27].

A higher frequency of genotypes $\mathrm{L} / \mathrm{L}$ and $\mathrm{L} / \mathrm{S}$ compared to genotype $\mathrm{S} / \mathrm{S}$ in the promoter of the serotonin transporter gene (5HTTL) was revealed in athletes as well as in the control group, which is consistent with the findings of other authors [28]. In a number of studies, a high correlation between genotypes with low expression of the serotonin transporter $\left(\mathrm{S} / \mathrm{S}, \mathrm{L}_{\mathrm{G} /} \mathrm{S}, \mathrm{L}_{\mathrm{G}} / \mathrm{L}_{\mathrm{G}}\right)$ and aggressive behavior was discovered [29]. In the study of athletes, decreasing of negativism and irritability and increasing of indirect aggression in individuals with genotype S/S was demonstrated comparing to individuals with genotypes S/L and $\mathrm{L} / \mathrm{L}$, which indicates the likely strengthening of control over the emotional sphere in individuals with genotype S/S [7].

When comparing the frequency of genotypes containing allele with 7 repeats with frequencies of other variants of DRD4E3 genotypes in judo athletes and controls, no significant differences between groups were revealed (Table 3). Previously, an association of this variant of DRD4E3 with a penchant for migration and the search for novelty has been demonstrated [30], as well as competitiveness, aggressiveness, as well as a willingness to take big financial risks [31].

In our study, no significant differences in frequency of genotype $10 / 10$ of the DAT1 gene in athletes and controls were discovered probably due to the low sample size of athletes (Table 3). Previously, for the distribution of this genotype in athletes the following features were identified: with increasing skills of athletes (athletes of the first- and second-classes - a candidate master - a master of sports) frequencies of genotype 10/10 increase and reach their maximum values in the group of candidate masters and masters of sports [32]. According to the literature, genotype $10 / 10$ of the DAT1 gene is associated with antisocial behavior in adolescents, and with aggression and delinquency [18]. Although, the differences in occurrence of $10 / 10$ variant of DAT1 
Citation: Butovskaya PR, Butovskaya ML, Vasilyev VA, Lazebny OE, Shibalev DV, et al. (2013) Molecular-Genetic Polymorphisms of Dopamine, Serotonin and Androgenic Systems as Molecular Markers of Success in Judo Wrestling Sportsmen. J Bioanal Biomed S3: 005. doi:10.4172/1948-593X.S3-005

Page 4 of 6

\begin{tabular}{|c|c|c|c|c|c|c|}
\hline \multirow{2}{*}{ Gene/genotype } & \multicolumn{3}{|c|}{ Judo Group } & \multicolumn{3}{|c|}{ Control Group } \\
\hline & & Hobs & Hexp & & Hobs & Hexp \\
\hline COMT & $N=16$ & & & $\mathrm{~N}=35$ & & \\
\hline V/V & $0.438 \pm 0.124$ & \multirow{3}{*}{0.438} & \multirow{3}{*}{0.466} & $0.143 \pm 0.059$ & \multirow{3}{*}{0.543} & \multirow{3}{*}{0.492} \\
\hline V/M & $0.438 \pm 0.124$ & & & $0.543 \pm 0.084$ & & \\
\hline $\mathrm{M} / \mathrm{M}$ & $0.125 \pm 0.083$ & & & $0.314 \pm 0.078$ & & \\
\hline$D R D 4 P r$ & $\mathrm{~N}=16$ & & & $\mathrm{~N}=40$ & & \\
\hline L/L & $0.625 \pm 0.121$ & \multirow{3}{*}{0.313} & \multirow{3}{*}{0.353} & $0.700 \pm 0.072$ & \multirow{3}{*}{0.275} & \multirow{3}{*}{0.276} \\
\hline L/S & $0.313 \pm 0.116$ & & & $0.275 \pm 0.071$ & & \\
\hline $\mathrm{S} / \mathrm{S}$ & $0.063 \pm 0.061$ & & & $0.025 \pm 0.025$ & & \\
\hline 5HTTLPR & $\mathrm{N}=16$ & & & $\mathrm{~N}=40$ & & \\
\hline $\mathrm{L}_{\mathrm{A}} / \mathrm{L}_{\mathrm{A}}$ & $0.125 \pm 0.083$ & \multirow{6}{*}{0.750} & \multirow{6}{*}{0.546} & $0.325 \pm 0.074$ & \multirow{6}{*}{0.525} & \multirow{6}{*}{0.538} \\
\hline$L_{A} / S_{A}$ & $0.688 \pm 0.116$ & & & $0.425 \pm 0.078$ & & \\
\hline$S_{A} / S_{A}$ & $0.125 \pm 0.083$ & & & $0.150 \pm 0.056$ & & \\
\hline $\mathrm{L}_{A} / \mathrm{L}_{G}$ & $0.063 \pm 0.061$ & & & $0.050 \pm 0.034$ & & \\
\hline$S_{A} / L_{G}$ & $0.000-$ & & & $0.050 \pm 0.034$ & & \\
\hline $\mathrm{L}_{G} \mathrm{~L}_{G}$ & $0.000-$ & & & $0.000-$ & & \\
\hline HTR1A & $N=16$ & & & $\mathrm{~N}=40$ & & \\
\hline $\mathrm{C} / \mathrm{C}$ & $0.438 \pm 0.124$ & \multirow{3}{*}{0.125} & \multirow{3}{*}{0.516} & $0.275 \pm 0.071$ & \multirow{3}{*}{0.600} & \multirow{3}{*}{0.495} \\
\hline C/G & $0.125 \pm 0.083$ & & & $0.600 \pm 0.077$ & & \\
\hline G/G & $0.438 \pm 0.124$ & & & $0.125 \pm 0.052$ & & \\
\hline HTR2A & $N=16$ & & & $\mathrm{~N}=36$ & & \\
\hline $\mathrm{A} / \mathrm{A}$ & $0.188 \pm 0.098$ & \multirow{3}{*}{0.313} & \multirow{3}{*}{0.466} & $0.111 \pm 0.052$ & \multirow{3}{*}{0.528} & \multirow{3}{*}{0.475} \\
\hline A/G & $0.313 \pm 0.116$ & & & $0.528 \pm 0.083$ & & \\
\hline G/G & $0.500 \pm 0.125$ & & & $0.361 \pm 0.080$ & & \\
\hline$D R D 4 E 3$ & $\mathrm{~N}=15$ & & & $\mathrm{~N}=39$ & & \\
\hline $2 / 4$ & $0.067 \pm 0.064$ & \multirow{8}{*}{0.467} & & $0.179 \pm 0.061$ & & \\
\hline $3 / 4$ & $0.000-$ & & & $0.026 \pm 0.025$ & & \\
\hline $4 / 4$ & $0.533 \pm 0.129$ & & & $0.513 \pm 0.080$ & & \\
\hline $4 / 5$ & $0.000-$ & & 0432 & $0.026 \pm 0.025$ & 0.462 & 0.459 \\
\hline $2 / 7$ & $0.067 \pm 0.064$ & & 0.702 & $0.026 \pm 0.025$ & & \\
\hline $3 / 7$ & $0.000-$ & & & $0.026 \pm 0.025$ & & \\
\hline $4 / 7$ & $0.333 \pm 0.122$ & & & $0.179 \pm 0.061$ & & \\
\hline $7 / 7$ & $0.000-$ & & & $0.026 \pm 0.025$ & & \\
\hline$D R D 2$ & $\mathrm{~N}=16$ & & & $\mathrm{~N}=38$ & & \\
\hline $\mathrm{A} 1 / \mathrm{A} 1$ & $0.000-$ & & & $0.026 \pm 0.026$ & & \\
\hline A1/A2 & $0.125 \pm 0.083$ & 0.125 & 0.121 & $0.342 \pm 0.077$ & 0.342 & 0.321 \\
\hline A2/A2 & $0.875 \pm 0.083$ & & & $0.632 \pm 0.078$ & & \\
\hline DAT1 & $N=16$ & & & $\mathrm{~N}=40$ & & \\
\hline $8 / 10$ & $0.000-$ & & & $0.025 \pm 0.025$ & & \\
\hline $9 / 10$ & $0.313 \pm 0.116$ & 0313 & 0272 & $0.500 \pm 0.079$ & 0,550 & Q 417 \\
\hline $10 / 10$ & $0.688 \pm 0.116$ & 0.010 & 0.272 & $0.450 \pm 0.079$ & 0.030 & 0.411 \\
\hline 10/11 & $0.000-$ & & & $0.025 \pm 0.025$ & & \\
\hline
\end{tabular}

Table 3: Genotype frequencies, observed and expected heterozygosities for the studied loci in Judo and Control groups.

gene in athletes and control group in our study were in same direction as had been found earlier [32], i.e. the linear increase of occurrence of $10 / 10$ genotypes with the increase of sportive achievements in shooting. Interestingly, the 10/10 DAT1 genotype had been associated with antisocial behavior in adolescents [31], as well as with aggression and delinquency [33].

Although in this study the association between the 7+ DRD4E3 genotype and athleticism we did not reach the level of significance, the obvious positive trend was found. Earlier it was suggested that $7+$ DRD4E3 allele was selected for behaviors associated with migration, male competitiveness, novelty seeing and risk taking [30,34].

Twin and family studies indicated that individual variations in personality traits and behavior are determined by genetic factors to a great extent (by almost 50\%). Particularly, some of the genes that affect the difference in aggressiveness are common for various types of aggressive behavior and certain temperament characteristics (emotionality and impulsivity). A common family environment is not an important determinant of aggressiveness in adults, while the individual environment accounts for at least half or its variance [35,36]. Obviously, environmental factors such as training, parental support play an important role in successful sportive career, but as mentioned above genetic factors do matter. Ten polymorphisms selected for analysis in this study are connected to the functioning of serotonergic, dopaminergic and androgenic systems according to other studies presumably may be associated with resistance to psychological stress, 
Citation: Butovskaya PR, Butovskaya ML, Vasilyev VA, Lazebny OE, Shibalev DV, et al. (2013) Molecular-Genetic Polymorphisms of Dopamine, Serotonin and Androgenic Systems as Molecular Markers of Success in Judo Wrestling Sportsmen. J Bioanal Biomed S3: 005. doi:10.4172/1948-593X.S3-005

emotional control, competitiveness and aggression [6-9,13,19,37]. Although the sample size in this study was quite low it is still possible to suggest that functionally important polymorphisms of genes in serotonergic system provide some evidence of strong selective pressure in direction of genotypes associated with low level of free serotonin in successful judo athletes. Due to this fact the carriers of such genotypes are predisposed for a better control of reactive aggression. In terms of dopaminergic system, it was demonstrated, that in elite judo athletes, the genotypes correlated with the low level of dopamine were overrepresented compared to control sample. Consequently, elite judo athletes were predisposed for better control of proactive aggression as well. The analyzed polymorphisms of COMT gene, and CAG repeats of AR gene, thus may be applied as the biomarkers sportive achievements in wresting.

\section{Acknowledgments}

This study was partly supported by the Russian Foundation for Basic Researches (12-04-31869a, 13-04-00858a, 13-06-00393a, and 11-04-96565 r south_c), the RAS Program "Molecular and Cell Biology", and the President RF Program (no. 5233.2012.4). We are especially grateful to athletes and students for participation in this study.

\section{References}

1. MacArthur DG, North $\mathrm{KN}$ (2005) Genes and human elite athletic performance. Human Genetics 116: 331-339.

2. Carat M, Colakoglu M, Erdogan A, Berdeli W, Cam FS (2006) Relationship between ACE genotype and short duration aerobic performance development. European J Appl Physiol 98: 461-465.

3. C Santiago, J R Ruiz, C A Muniesa, M González-Freire, F Gómez-Gallego, A Lucia (2010) Does the polygenic profile determine the potential for becoming a world-class athlete? Insights from the sport of rowing. Scandinavian Scand J Med Sci Sports. 20: e188-e194.

4. Sawczuk M, Maciejewska A, Cięszczyk P, Eider J (2011) The role of genetic research in sport. Science \& Sports 26: 251-258.

5. Sessa F, Chetta M, Petito A, Franzetti M, Bafunno V, et al. (2011) Gene Polymorphisms and Sport Attitude in Italian Athletes. Genet Test Mol Biomarkers 15: 285-290.

6. Melman RB, Dina C, Zohar AH, Constantini N, Lerer E, et al. (2005) AVPR1 and SLC6A4 Gene Polymorphisms Are Associated with Creative Dance Performance. PloS Genetics 1: 0394-0403.

7. Maluchenko NV, Schegolkova JV, Kulikova MA, Timofeeva MA, Shlepcova VA, et al. (2009) Gender effects on association of serotonin transporter gene polymorphism with symptoms of central fatigue. Bulletin of Experimental Biology and Medicine 147: 462-465.

8. Sysoeva OV, Maluchenko NV, Timofeeva MA, Portnova GV, Kulikova MA, et al. (2009) Aggression and 5HTT polymorphism in females: Study of synchronized swimming and control groups. Int J Psychophysiol 72: 173-178.

9. Butovskaya ML, Vasilyev VA, Lazebny OE, Burkova VN, Kulikov AM, et al. (2012) Agression, digit ratio, and variation in the androgen receptor, serotonin transporter, and dopamine D4 receptor genes in African foragers: the Hadza. Behav Genet 42: 647-662.

10. Armin Heils, Andreas Teufel, Susanne Petri, Gerald Stöber, Peter Riederer, et.al. (1996) Allelic variation of human serotonin transporter gene expression. J Neurochem 66: 2621-2624.

11. Xian-ZH, Lipsky HR, Zhu G, Akhtar LA, Taubman J, et al. (2006) Serotonin transporter promoter gain-of-function genotypes are linked to obsessivecompulsive disorder. Am J Hum Genet 78: 815-826.

12. Adayev $Y$, Ranasingne $B$, Banarjee $P$ (2005) Transmembrane signaling in the brain by serotonin, a key regulator of physiology and emotion. Biosci Rep 25: 363-385

13. Vasiliev VA, Martirosyan IA, Shibalev DA, Kulikov AM, Lazebny OE, et al.
(2011) Polymorphism of the dopamine D4 receptor (DRD4) and serotonine transporter (5-HTTL) gene promoter regions in African tribes of Hadza and Datoga. Russian Journal of Genetics 47: 226-229.

14. Seaman MJ, Fisher JB, Chang FM, Kidd KK (1999) Tandem duplication polymorphism upstream of Dopamine D4 Receptor gene (DRD4). Am J Med Genet B Neuropsychiatr Genet 88: 705-709.

15. Kereszturi E, Kiraly O, Barta C, molnar N, Sasvari-Szekely M, et al. (2006) No direct of the $521 \mathrm{C} / \mathrm{T}$ polymorphism in human dopamine D4 receptor gene promoter on transcriptional activity. BMC Mol Biol 7: 18.

16. Asherson $P$ (2004) Attention-deficit hyperactivity disorder in post genomic era. European Child \& Adolescent Psychiatry 13: 50-70.

17. Persico AM, Bird G, Gabbay FH, Uhl GR (1996) D2 dopamine receptor gene Taq I A1 and B1 restriction fragment length polymorphisms: enhanced frequencies in psychostimulant-preferring poly-substance abusers. Bio Psychiatry 40: 776-784.

18. Lachman HM, Papolos DF, Saito T, Yu YM, Szumlanski CL, et al. (1996) Human catechol-O-metyltrasferase pharmacogenetics: description of functional polymorphism and its potential application to neuropsychiatric disorders. Pharmacogenetics 6: 243-250.

19. Kulikova MA, Maluchenko NV, Timofeeva MA, Shlepzova VA, Schegolkova $\mathrm{JV}$, et al. (2008) Effect of functional catechol-O-methyltransferase Val158Met polymorphism on physical aggression. Bulletin of Experimental Biology and Medicine 145: 62-64.

20. Chamberlain N, Driver E, Miesfeld RL (1994) The length and location of CAG tri-nucleotide repeats in androgen receptor $\mathrm{N}$-terminal domain affect transactivation function. Nucleic Acids Res 22: 3181-3186.

21. Wang HY, Hu Y, Wang SH, Shan QL, Li YC, et al. (2010) Association of androgen receptor CAG repeat polymorphism with $\mathrm{VO}_{2}$ max response to hypoxic training in North China Han men. Int J Androl 33: 794-799.

22. Butovskaya ML, Veselovskaya EV, Godina EZ, Tretyak AV, Silaeva LV (2011) Morphofunctional and personality characteristics of male sportsmen as a mode of adaptive sets of traits in paleoreconstructions. Moscow State University Bulletin. Series XXIII Anthropology 2: 4-15.

23. Butovskaya ML, Veselovskaya EV, Kondratieva AV, Prosikova EA (2012) Morpho-psychological complexes as indications of success in sport: women. Moscow State University Bulletin. Series XXIII Anthropology 2: 29-42.

24. Madland NG, Duffy DL, Spurdle AB, Wright MJ, Geffen GM, et al. (2005) Opposite effects of androgen receptor CAG repeat length on increased risk of left-handedness in males and females. Behav Genet 35: 735-744.

25. Hampson E, Sankar JS (2012) Hand preference in humans is associated with testosterone levels and androgen receptor gene polymorphism. Neuropsychologia 50: 2018-2025.

26. Gursoy R (2009) Effects of left- or right-hand preference on success of boxers in Turkey (2009) Br J Sports Med 43: 142-144

27. Manning JT, Taylor RP (2001) Second to fourth digit ratio and male ability in sport: implications for sexual selection in humans. Evol Hum Behav 22: 61-69.

28. Sysoeva OV, Maluchenko NV, Timofeeva MA, Portnova GV, Kulikova MA, et al (2009) Aggression and 5HTT polymorphism in females: Study of synchronized swimming and control groups. International Journal of Psychophysiology 72 : 173-178.

29. Haberstick BC, Smolen A, Hewitt JK (2006) Family Based Association Test of the 5HTTLPR and Aggressive Behavior in a General Population Sample of Children. Biol Psychiatry 59: 836-843.

30. Dreber A, Apicella CL, Eisenberg DTA, Garcia JR, Zamore RS, et al. (2009) The 7R polymorphism in the dopamine receptor $\mathrm{D} 4$ gene (DRD4) is associated with financial risk taking in men. Evol Hum Behav 30: 85-92.

31. Vaughn C, Leff J (2011) The Measurement of Expressed Emotion in the Families of Psychiatric Patients. British J Soc Clin Psychol 15: 157-165.

32. Churnosov MI, Sobjanin FI, Sokorev VV, Lependina IN, Rudich NA, et al (2007) Gene polymorphism in athletes. Theoretical-science journal "Scientific Notes" 4: 100-106. 
Citation: Butovskaya PR, Butovskaya ML, Vasilyev VA, Lazebny OE, Shibalev DV, et al. (2013) Molecular-Genetic Polymorphisms of Dopamine, Serotonin and Androgenic Systems as Molecular Markers of Success in Judo Wrestling Sportsmen. J Bioanal Biomed S3: 005. doi:10.4172/1948-593X.S3-005

Page 6 of 6

33. Burt SA, Mikolajewski AJ (2008) Preliminary evidence that specific candidate genes are associated with adolescent-onset antisocial behavior. Aggress Behav 34: 437-445.

34. Ding Y-Ch, Chi H-Ch, Grady DL, Morishima A, Kidd JR, et al. (2002) Evidence of positive selection acting at the human dopamine receptor D4 gene locus. PNAS 99: 309-314
35. Alfimova MV, Trubnikov VI (2000) Psychogenetics of aggression. Voprosy Psikhologii 6: 112-122.

36. Slutske WS (2001) The genetics of antisocial behavior. Curr Psychiatry Rep 3: $158-162$.

37. Vasilyev VA (2011) Molecular psychogenetics of deviant aggressive behavior in humans. Russian Journal of Genetics 47: 1023-1032. 